Society for the Anthropology of Work • Essential Labor

Chronic, Not Crisis: Why

We Need More than

Sympathy to Talk About

Worker Health

Oğuz Alyanak

Published on: Oct 16, 2020

DOI: 10.21428/1d6be30e.dbd79956

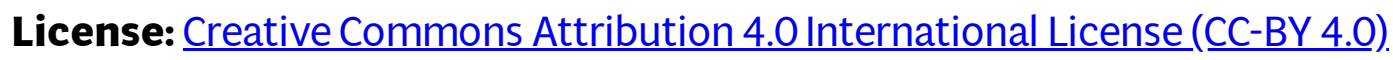


In recent months, I have been reading about workers-essential workers, as we call them now-whom we have lost to COVID-19. There are hundreds of obituaries on the web, beautifully written pieces that are filled with grief. "A number provides an answer to how many, but it can never convey the individual arcs of life, the 100,000 ways of greeting the morning and saying goodnight," wrote the New York Times back in May. Although what we are experiencing is novel, the writers at Time suggested, we should find common ground in our mourning for workers who died during the pandemic, adding: "Let us think of them with wet eyes and a high heart."

These calls for sympathy are forms of public sentiment that cannot be dismissed, and yet they risk obscuring the roots of worker harm in a political and economic system with a well-established record of "prioritizing_profit over human life." It is a fact that COVID-19 kills. But harsh working conditions, which were in place long before the pandemic hit, do as well. Globally, over two and a half million workers die each year due to workplace-related injuries. An additional 310 million suffer injuries at work, while still others develop chronic anxiety and other occupational stress-related conditions as they try to provide for their families. Yet, as we speak of COVID-19 as the prime culprit, we tend to forget that workers-essential or not-have been sick and dying all along.

Recai Bey is one such man. He has been running a tiny döner kebab shop (or imbiss, as they are called in the German city of Göttingen) for twenty-three years. This is an admirable feat, given the harsh working conditions that drive most imbiss owners to hand over the business after a couple of years.

When I visited Recai Bey in May 2020, he greeted me behind a plastic panel separating the kitchen from the guest room, which had been installed per the city's COVID-19 regulations. We sat down to talk about life at work amid the pandemic. I wanted to know if the virus and the concomitant lockdown had made things harder, and whether he feared exposure. Nothing was different, he told me, other than having closed the shop for five weeks and the mask that he had to wear now that it had reopened. 


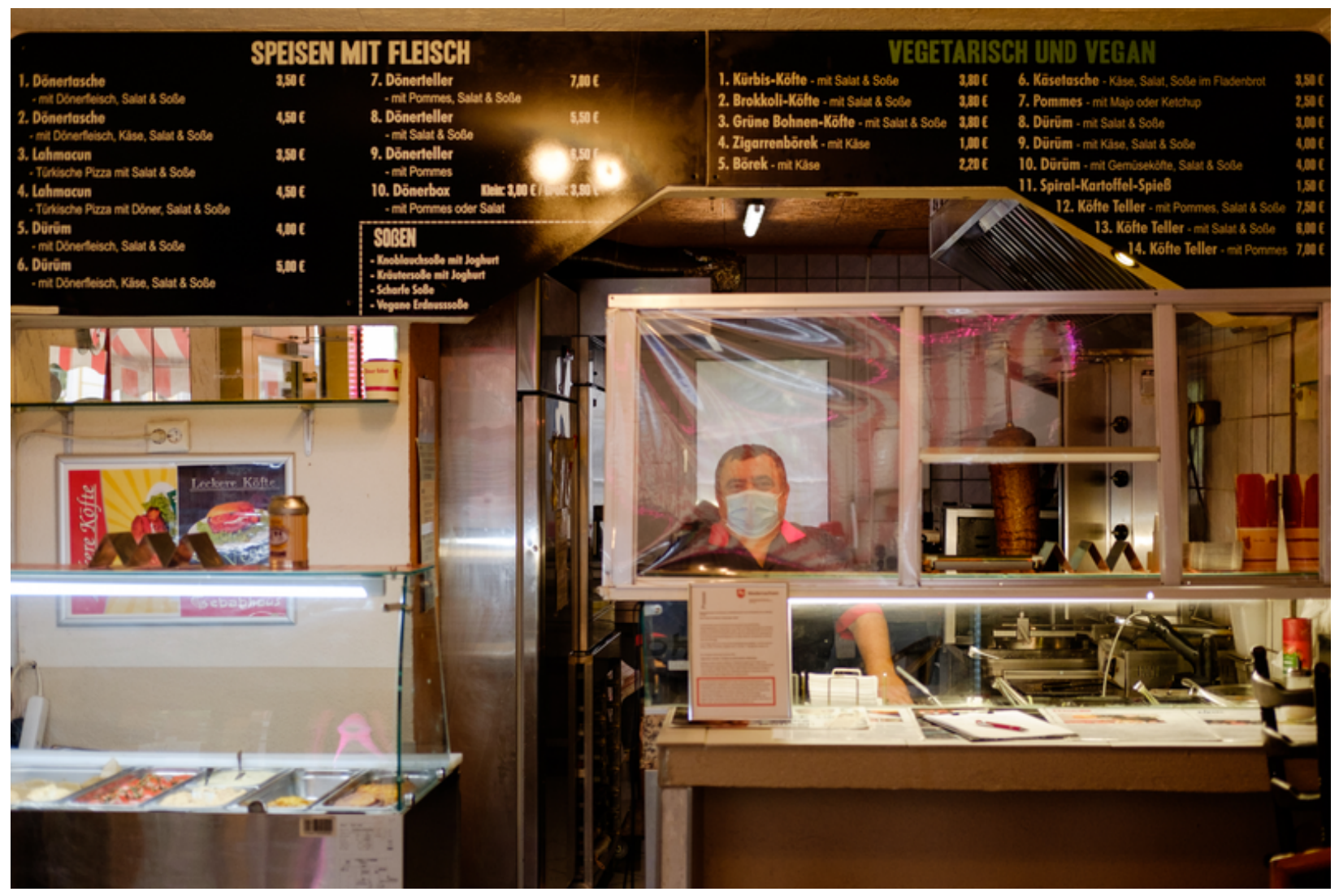

Recai Bey in his imbiss in Göttingen, 2020. Photo by Oğuz Alyanak.

This statement came as quite a surprise, given what I had been reading about the lifealtering consequences of the pandemic for workers, including those in the food services sector. Recai Bey's imbiss was closed when the lockdown was in effect in Germany-a closure for which he was compensated by the German state-but his workplace was also one of the first to open when the lockdown was lifted. He was back on the frontline. Yet he did not complain. The imbiss, Recai Bey explained, was like a child who needed attention. Work begins long before the restaurant opens and it ends when the last customers leave, usually after midnight. Imbiss work also leaves on the body a scent of burned meat and french fries that no amount of water and soap can clear out. Although duties can be shared among different members of the family, and in rare instances, through employment of additional workers, it is often the same faces you see behind the counter day in and day out.

But for Recai Bey, the alternatives to working at the imbiss were worse. When he arrived in Germany from Turkey some thirty years ago, he took a job in a steel factory. He had to work under the intolerable heat emanating from heavy machinery, and in a regimented work schedule where he had to ask permission to even use the toilet. Back in Turkey, Recai Bey had been trained as an electrician. It was not the demotion that 
bothered him, but the working environment. He told me that had he continued the job in the factory or found employment at a construction site like most other Turks, he would have ruined his health by now.

Work in menial jobs, which a majority of migrant workers do due to lack of skills or alternative job opportunities, is physically and mentally debilitating. Recai Bey, for example, considered himself in good health, yet during our interview, he rubbed his right elbow every now and then as if to placate a pain. When I pointed it out, he told me that his doctor had told him that his elbow tendon was inflamed. "Nothing serious," he added.

Inflammation of the elbow is a typical ailment associated with imbiss work. As much of the work is repetitive-shaving meat hundreds of times a day-it takes its toll first on elbows and shoulders. Legs break down as a result of varicose veins and rheumatism. Other menial jobs have different ailments associated with them. In construction, for example, workers take sick days or opt for early retirement due to hernias; and on factory assembly lines, due to damaged or missing body parts. During fieldwork that I carried out in the French city of Strasbourg, I met the uncle of a young Turkish man, Alparslan. Alparslan's uncle had undergone surgeries on both of his shoulders and visited a physiotherapist regularly, as the result of years spent in a döner kebab shop. Once, to show me the extent of his condition, he tried lifting his arms over his head but simply could not. Luckily, he had sons who could take over the shop and insurance that would pay for his medical needs. But with damaged shoulders, he would never be able to work the way he once did.

A man in his late twenties, Alparslan had moved to France some fifteen years ago and worked in construction and meat packaging jobs upon his arrival. He had vivid memories of loading frozen chickens on pallets, which he found physically constraining. Soon after, he decided to take matters into his own hands. After taking a loan from his uncle, he opened a snack döner shop of his own. The plan was to run it with his wife, but with a baby on the way, she started taking days off. So, as part of my research, I started working half-day shifts at the shop, learning the tricks of the trade and observing the working conditions while also helping a key informant.

Like Recai Bey, Alparslan worked long hours; spending more than twelve hours in front of the gyrating skewers for six to seven days a week literally made a new man out of him. Some of the changes were less visible-like the calluses I formed after spending a few weeks shaving meat, slicing pita bread, dicing veggies, and wiping 
floors and countertops. Having worked in menial jobs before, Alparslan already had strong hands and a tough skin. Calluses were the least of his problems.

A health issue that Alparslan could not ignore was the seasonal flu. As getting sick meant taking time off from work and, by extension, losing money, each time he could feel his immune system fighting off illness, he took pills to boost it. And when he did get sick, he made sure not to show it by smothering his coughs so that his customers would not be chased away.

Another issue was the inability to maintain a healthy diet. Early on, Alparslan brought food to the shop from home and brewed tea each morning, drinking it throughout the day. Yet reheating food and enjoying a cup of tea eventually became luxuries, too. As work picked up pace and customers started to roll in, he started eating the very döners that he served, which are relatively healthy but surely not the cornerstone of a daily diet. Alparslan gained weight and, by the time I had completed my fieldwork, his posture was hunched.

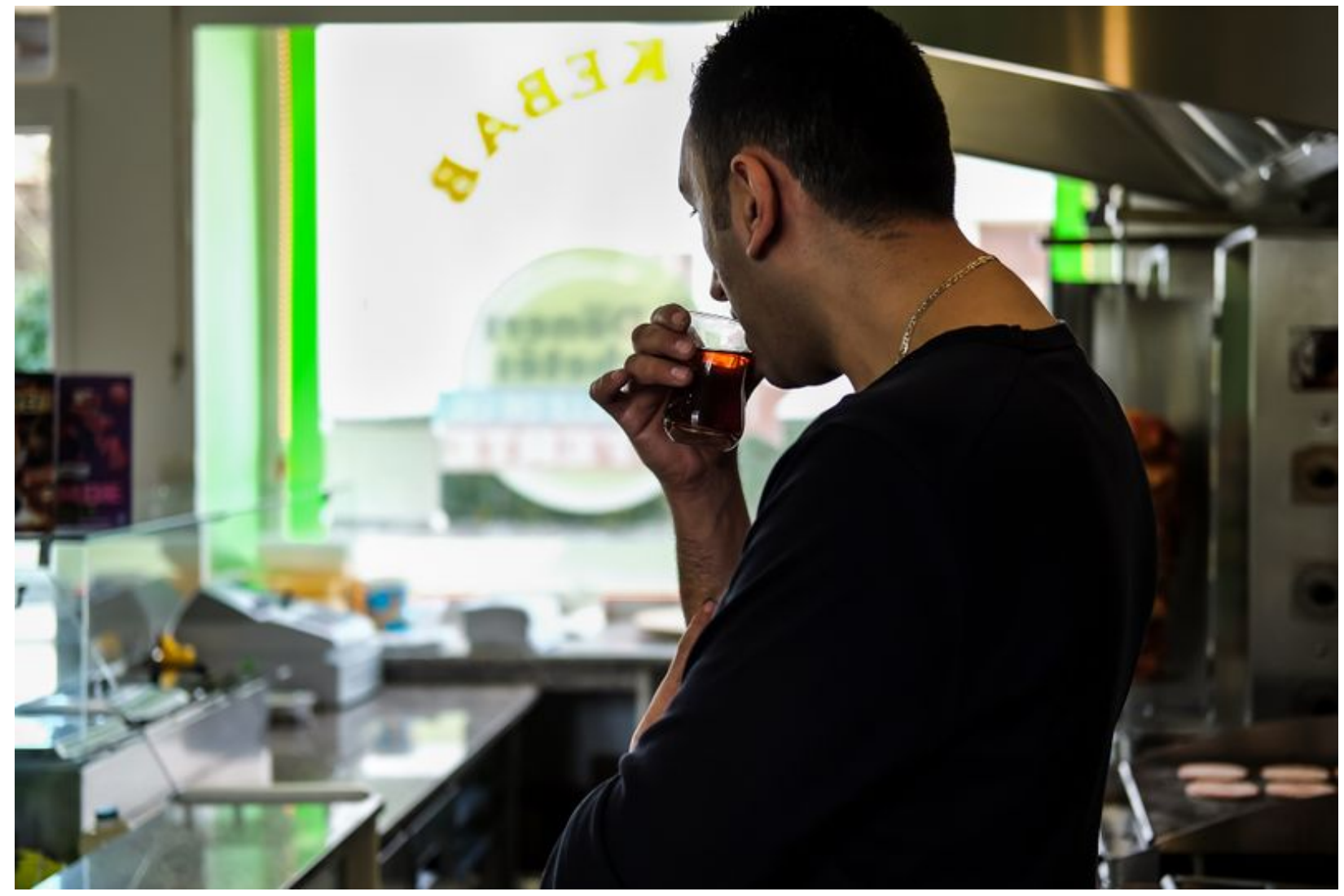

Alparslan sipping tea while waiting for customers, 2016. Photo by Oğuz Alyanak.

What was still harder to cope with were the mental constraints associated with work. Alparslan's main goal in running the shop was to provide for his family. But the very 
family he provided for was one he could barely see. By the time he closed the shutters it was midnight, and his kids were fast asleep. The only time he could see them was when he drove them to kindergarten, or when his wife brought them over after school for a short visit.

The same was true for Recai Bey, whose time in the imbiss came at the expense of family and social life. Work was even more consuming when he first opened the imbiss, sleeping for several months at the shop in a makeshift bed in the cellar while waiting for the pita dough to rise. Sometimes his kids slept in the workplace too, on top of a jacket that he folded up under the counter, while he and his wife kept the imbiss open late to build the business. Now that he had been running an imbiss for over two decades, I expected him to make more time for his family. But I was wrong. When I asked how often he got to enjoy a cup of coffee with his wife, Recai Bey responded that they did make time for that. "Last week, for example, after we closed the imbiss," he recalled. "After you closed the imbiss?" I asked. and "That must have been after midnight!" It was. The two went to McDonald's, the only place that was open that late, to grab a rare cup of coffee together.

As the pandemic gains strength again in both Germany and France, we are told that life and its routines are different. But, in some sense, not for Recai Bey, Alparslan, or other workers who have been putting their health in jeopardy all along. Recai Bey continues to spend long days at the spit. I see him behind the counter each time I pass his shop. I presume that the same is true for Alparslan, whom I have not been able to see in months.

Do I feel sympathy for these men? Certainly. They make do amid very real constraints, and I can only admire their work ethic. Yet I also feel a strong sense of frustration. In thinking on my time in Alparslan's snack döner and my conversations with Recai Bey, I cannot help asking why it is that these men have to work so hard for so little-and why it has to come at the expense of their health.

The COVID-19 moment may be an opportune one in which to highlight the precarity of workers like these. Yet, as Elizabeth Povinelli (2011: 13) reminds us, these "catastrophic, crisis-laden, and sublime" moments can threaten to overshadow "the ordinary, chronic, and cruddy." A critical anthropology of work demands asking what an all-encompassing event like a pandemic does to our sense of context, and how exceptional calls for sympathy can make us forget the chronicity of the current condition. Workers are not sick or dying just because of the virus. They have been sick and dying all along. 


\section{Author Bio}

Oğuz Alyanak is Volkswagen Foundation Postdoctoral Fellow at the University of Göttingen and the editorial assistant for social media at Medical Anthropology. His dissertation, which he defended in Washington University in St. Louis in 2019, was on Muslim men's night lives at the Franco-German borderland. His current research explores occupational injuries and illnesses among Turkish immigrants in Europe.

\section{Preview Image}

Courtesy of Gilbert Mercier.

\section{Reference}

Povinelli, Elizabeth A. 2011. Economies of Abandonment: Social Belonging and Endurance in Late Liberalism. Durham, NC: Duke University Press. 